\title{
THE MORAL AND A POLITICAL PORTRAIT OF GREAT FIGURES OF HISTROY IN THE LIBRARY OF HISTORY OF DIODORUS SICULUS
}

Cynthia Cristina de Morais Mota ${ }^{1}$

\begin{abstract}
The article deals with the importance given to the war by historians of antiquity as an important part of his narrative construction and description of the deeds of great men. It seeks to deepen the importance of the war for the construction of men considered wise and important to the historian Diodorus of Sicily as the story is, for him, a court, where everyone will be judged for good or for evil.
\end{abstract}

\section{Keywords}

Wars in Ancient World; Hellenistic Historiography; Diodorus of Sicily; Epaminondas; Thebes.

\section{Resumo}

$\mathrm{O}$ artigo trata da importância dada à guerra pelos historiadores da Antiguidade como parte importante de sua construção narrativa e da descrição dos feitos dos grandes homens. Busca-se aprofundar a importância da guerra para a construção de homens considerados sábios e importantes para o historiador Diodoro de Sicília visto que a história é, para ele, um tribunal, onde todos serão julgados para o bem ou para o mal.

\section{Palavras-chave}

Guerras na Antiguidade; historiografia helenística; Diodoro de Sicília; Epaminondas; Tebas.

\footnotetext{
${ }^{1}$ Assistant Professor, Federal University of Rondônia, Rolim de Moura, Brazil. E-mail: cythiacristina@unir.br
} 
The ultimate goal of war must be peace. Aristotle, Politics, VII, 1333 a.

The only reason to wage a war is the desire to live in peace without injustice. Cicero, De officiis, 11, 34.

War, forger of Great Men: the role of Parádoxa (unexpected) and of the Fortune $(T y \bar{c} h \bar{e})$ in the understanding of the history

Although it is a truism, the ancient world as a whole, was marked heavily by the war. The great empires of antiquity were based on the continuous conquest of peoples and territories, with a frightening violence. The Assyrians, notorious for the continuous and systematic use of violence, promoted killings and mass deportations of the defeated populations. In Mesopotamia, in its various historical phases, the war had an important role in taking (and destruction) the cities and people. Entire populations lived at the mercy of endless wars; any political stability was always transient, since that depended on the success of the kings and leaders on the battlefield. A quick reading of the texts that make up the biblical Old Testament shows us that Yahweh was, above all, the God linked to war, and one of his epithets was "Yahweh, the Lord of the armies." This image also reminds us of the sacred component, present in the acts of the warriors, with ceremonies and sacrifices offered to the gods, and the existence of gods who had the main prerogative to be co-participants of the acts involving the war. The Mesopotamian kings accumulated war and religious functions and both were closely linked. Rituals were performed in order to please them so that they remained alongside the army against the enemy. In recognition of the victories, part of the booty of war was offered to the shrines and gods. Significant passage, which shows the importance of divine intercession in battle, is the conquest of Jericho made by Joshua (Joshua, 5, 13-27) 2. Complex rituals were performed, along with the priests, so that the city could be conquered. All the symbolic elements that contribute to the sacralisation of the war and violence that it generates are justified in the anathema, ie, the share that belongs to the god of what has been achieved, thanks to his divine intervention. Although one can not generalize the behaviour of all peoples, putting them under the same interpretive perspective, it is a fact that religion played a decisive role for the justification of killing (with all

\footnotetext{
2 "But you, beware of the curse, so that you do not take anything of what is anathema, driven by greed, because that would turn anathema into a camp of Israel and bring it on confusion. All silver and all gold, all objects of bronze and iron will be dedicated to Yahweh; they will be part of its treasure."
} 
the moral consequences that it entails) and gets hold of the goods of the opponent. It was necessary a range of incentives for a man to be engaged in direct combat with another man. The divine presence was required and even necessary for such ventures to obtain success. In the Iliad, the gods are so present that the heroes only perform what they had already planned:

Then, stirred to hot anger, spake to her Zeus, the cloud-gatherer: "Strange queen, wherein do Priam and the sons of Priam work thee ills so many, that thou ragest unceasingly to lay waste the well-built citadel of Ilios? If thou wert to enter within the gates and the high walls, [35] and to devour Priam raw and the sons of Priam and all the Trojans besides, then perchance mightest thou heal thine anger. Do as thy pleasure is; let not this quarrel in time to come be to thee and me a grievous cause of strife between us twain. And another thing will I tell thee, and do thou lay it to heart. [40] When it shall be that I, vehemently eager to lay waste a city, choose one wherein dwell men that are dear to thee, seek thou in no wise to hinder my anger, but suffer me; since I too have yielded to thee of mine own will, yet with soul unwilling. For of all cities beneath sun and starry heaven [45] wherein men that dwell upon the face of the earth have their abodes, of these sacred Ilios was most honoured of my heart, and Priam and the people of Priam, with goodly spear of ash. For never at any time was mine altar in lack of the equal feast, the drink-offering, and the savour of burnt-offering, even the worship that is our due.

Although Homer does not describe the Trojan War, it is clear in the poem the significant role of the gods in the course of events parallel to the war. It is necessary to please them with sacrifices and libations, so that they stay with them in the decisive moments, which in both epic and historiography, it meant to be with the warrior at the time of the battle and at its height, the collision, the timing of the shock of the two armies. (Clausewitz, 2003: 107) The sacrifices are essential, as well the dialogue between Zeus and Hera denotes well. (Romilly, 1998: 74-75) shows how the Iliad, even though a work that deals with war, does not contain reports of battles. Most of the poem is centred on stories of single combats, presented in sequence: there is no trigger that places the battles in an order. What stands out most is the role of the hero and the glory achieved by him.

Homer always narrates what type of weapon is used, which organ it hits, what kind of death results from this, highlighting the curious wounds, of a spectacular and unexpected effect. The interest of these descriptions, therefore, is not only moral but also technical. However, both in a domain and in the other, it is to the value of the individual that all the attention is focused. Again, one should have a reservation, since these aristeîai, which are the Homeric battles, are adulterated, in our eyes, by one remarkable fact: the one putting the courage or fear in the heart of the fighter, who heads the spear or shifts it is, quite often, a god. When we estimate to be going for an accurate result, we find 
that it "would surely have happened if at this moment a god ...had not interfered. (Romilly, 1998: 74-75)

Two important points highlighted by Romilly will be added to the narratives of the future historians, when they talk about the war: the importance of a particular figure in the course of the battle (what kind of behaviour the commander and his soldiers had as they fought, and if they reached the glory) and the role of the unexpected, of the unexpected in human affairs (which is shown more clearly in the war, since the theme was the favourite of the Greek historians). For Homeric, the unexpected is represented by the direct intervention of the gods (even if disguised), but even in Herodotus, the gods do not fail to intervene, especially by the conversation with them undertaken through the oracles ${ }^{3}$ (that appear in all stories) or in the figure of the Divine Providence (Herodotus, III, 108, tôu theiou he pronoiê) that organizes and gives meaning to nature (phýsis). Legrand, editor and translator of Herodotus to the Budé editions, he says that since the sixth century, the idea of an intelligence governing the universe appeared in the philosophy of Eleatic Xenophanes of Colophon (nóou phrení pánta chradainei) and it was then resumed especially by Anaxagoras. (Herodote, 1967: 150) Herodotus refers to the Divine Providence in a description that he gives of the animals of Arabia, a region infested with snakes: the Divine Providence plays a regulatory role in the nature since, with his immense wisdom, he made the venomous animals like the snake, had low fecundity; a world that is infested with animals of this species would be terrible for the human existence. Nevertheless, harmless animals like the hare, for example, were extremely fruitful so that they could serve as food for others. Certainly it is a rationalization of the divine intervention, in both human and nature sphere, since the Divine Providence acts "naturally" so that things are organized at the best possible way and thus benefiting all. But we should not expect too much of Herodotus, as the author attaches great importance to the gods in his narrative, but not exactly the way that Homer did. Let us take as an example a very significant passage of the histories:

You see how the god smites with his thunderbolt creatures of greatness and does not suffer them to display their pride, while little ones do not move him to anger; and you see how it is always on the tallest buildings and trees that his bolts fall; for the god loves to bring low all things of surpassing greatness. Thus a large army is destroyed by a smaller, when the jealous god sends panic or the thunderbolt among them, and they perish unworthily; for the god suffers pride in none but himself. Now haste is always the parent of failure, and great

3 "I do not dare to make objections about the oracles and I do not allow others to do so" (VIII, 77). 
damages are likely to arise; but in waiting there is good, and in time this becomes clear, even though it does not seem so in the present.

It takes wisdom to see signs that denote the time when the gods send "messages", because not all of them are ready to decode such signs. This blindness is often caused by hýbris, which prevents man from seeing the truth that is imminent, disabling him with his pride, to put himself into his proper place. As it is easy to see the preference of the Greek historiography in narrating events related to war, it is noted that, in addition to individual competence, demonstrated by the generals on the battlefield, it is not, however, exclusively their own merit. Often, the events do not occur as planned, since chance in human affairs attests that everybody is subject to the setbacks of life. However it is noticed that the "chances" are not completely random. Chance4, represented by the Greek word týche is a goddess found A Theogony of Hesiod and is part of the lineage of Uranus and Tethys (360). Since the fourth century the goddess was worshiped in the cities of Thebes, Athens, Megara and Megalopolis (the land of Polybius, an author who gives Fortune an important role in his work) under the name of Agathé Týchēe (Pötscher, 1979: 1016-1017) however chance is not the only possible meaning of týche: it may involve contradictory meanings as fate, happiness or unhappiness. It implicitates in it the idea that something unexpected can happen and, therefore, it was not less important for men to worship it in an attempt to control, even on a provisional basis, the share that belongs to each one, in the wheel of endless events of life, as well remembered by Herodotus to justify his narrative:

These are the stories of the Persians and the Phoenicians. For my part, I shall not say that this or that story is true, but I shall identify the one who I myself know did the Greeks unjust deeds, and thus proceed with my history, and speak of small and great cities of men alike. For many states that were once great have now become small; and those that were great in my time were small before. Knowing therefore that human prosperity (eudaimoniēn) never continues in the same place, I shall mention both alike.

In fact, along with Fortune, moira potmos (fate personified, imperious, inflexible and which takes everything to its end, Iliad, 24, 209) ${ }^{5}$ are

\footnotetext{
${ }^{4}$ It seems almost a rule the "blindness" of the signs so clearly sent by the gods.

${ }^{5}$ In the Theogony, Moira is the daughter of Zeus and Themis in charge of the affairs of mortal men (904). But Hesiod also lists her as a daughter of the night (that gave birth to them alone), "and the Moira ( Fates ) to whom wise Zeus gave the greatest honor". The goddesses were invoked when it was necessary to swear an oath.
} 
associated, agathós (Liddel-Scott-Jones, 1989), daímōn 6, which gives it a tone often supernatural of the divine interference, demonstrating that the man does not control his destiny. At the same time, the inclusion of Fortune in the narrative gives the historian great freedom to manage the course of events, according to his methodological perspective and his personal beliefs regarding the role of history and the fate of his main characters. The case of Polybius is very illustrative:

There is this analogy between the plan of my History and the marvellous spirit of the age with which I have to deal. Just as Fortune (týchē) made almost all the affairs of the world incline in one direction, and forced them to converge upon one and the same point; so it is my task as an historian to put before my readers a compendious view of the part played by Fortune (týchē) in bringing about the general catastrophe.

It was this peculiarity which originally challenged my attention, and determined me on undertaking this work. And combined with this was the fact that no writer of our time has undertaken a general history. Had anyone done so my ambition in this direction would have been much diminished? But, in point of fact, I notice that by far the greater number of historians concern themselves with isolated wars and the incidents that accompany them: while as to a general and comprehensive scheme of events, their date, origin, and catastrophe, no one as far as I know has undertaken to examine it. I thought it, therefore, distinctly my duty neither to pass by myself, nor allow any one else to pass by, without full study, a characteristic specimen of the dealings of Fortune (týchē) at once brilliant and instructive in the highest degree. For fruitful as Fortune is in change, and constantly as she is producing dramas in the life of men, yet never assuredly before this did she work such a marvel, or act such a drama, as that which we have witnessed.

Polybius sees the hopeless victory of the power of Rome and sees in Fortune the only force able to explain such rapid rise. Anibal's War, which could have easily led Rome to its collapse, was, otherwise, the opportunity for the Romans to show their genius and hold their heads up, even in great misfortunes, and especially to know how to handle the "unexpected" in their favour. Who would ever say that Hannibal would defeat the Roman army so badly? In adittion to it, who would ever say that the Romans would be able to reconstruct a shattered army to impose a defeat and annihilate the Carthaginian power over the whole Mediterranean? Such is the wonder of Polybius, that also makes him do credit to Fortune 7 and the way men deal with it, the success of the Romans. Far from being a "neutral" factor, the use of Fortune allows the

\footnotetext{
${ }^{6}$ God or Goddess (Iliad, I, 222) or like a god, with the assistance of one God, the favour of a god (kata daimon, Herodotus, I, 111), according to the pleasure of the gods, the will of gods, chance (along with týchèn [týchèn kai damona]), the fortune, chance, luck.

7 Polybius also discusses the role of the constitutions to analyze how each people has become (or not) politically powerful. For obvious reasons, I will not cover this issue.
} 
historian to tell about the most diverse destinations of important figures, without taking sides in terms of people or a city, so explicitly. After all, if things had a specific end and not another, it was not "chance" or the "implacable fate" that made things happen exactly as they should? If Fortune has in it the component of the unexpected, it also serves as a "tool" for the "neutrality" of who writes the history. Greek historians liked to interlink their narrative so that the story gained a sense of continuity even though the events described could have occurred at different times and places in time and space. This made it possible that the unexpected element could gain importance and give meaning to the narrative, even when, apparently, such events were not linked.

Diodorus at this point, is not different from his predecessors: he appreciates and gives preference to the reports of battle, describing the behaviour of his characters; however, as our historian is a moralist who urges his readers to virtue, he gives preference in his narrative, to the role played by some figures in particular, who he clearly identifies with. 8These narratives happen quite often in the so-called historical books, that is, from the eleventh book (the books with historical narratives [after the Trojan War] that remain integral up to the volume XX). Amazingly, the characters of Diodorus have in some way, "their biographies written," because the story is the court where everyone should be judged for their deeds, for the good or for the evil. Such biographies tend to show the judgments of values that Diodorus makes about the characters, and his "sympathy" and "antipathy" towards them is clear. The chosen passages are those that contain the term parádoxa with the sense of "unexpected" or "contrary to all expectations"; such passages also show the intervention of Fortune or Divine Providence, portraying that such individuals were worthy of some type of unexpected and sometimes supernatural intervention. In order to understand how Diodorus approaches these characters and the role they occupy in educational history, is necessary to examine some of these characters who played important roles in his narrative to such an extent that he set aside his concern about the "symmetry".

Diodorus of Sicily was born in Agyrium in Sicily, west of Mount Etna (also known as Diodorus Agírion, According to some authors), around the year 90. ${ }^{9}$ Through his contacts with the Romans who inhabited the island, he learned the Latin language, which facilitated his research in the archives (I, IV, 4). Virtually everything we know about his life we are told

\footnotetext{
8 From the perspective of his conceptions of history.

${ }^{9}$ All dates cited in this work are prior to the Common Era, unless when explicitly said.
} 
by himself in the Historical Library (HL). (Canfora: 2001, 61). ${ }^{10}$ It took Diodorus thirty years to write his work, which cost him many difficulties (I, IV, 1). Farrignton apud Lens Tuero (1994: 33) assumes that he was an economically independent man, since he could have free time to do a great deal of research and travel. He visited Egypt, where he remained for four years and researched at the most important library of the ancient world: Alexandria. Diodorus refers to his stay in Egypt in different periods of $H L$. The Library of Diodorus consisted of 40 books, whose structure is explained by the author in the preface (HL, I, I-VI): the first six dealt with the mythic narratives preceding the Trojan War, the first three are devoted entirely to non-Greek peoples and the last three ones, nearly exclusively to the Greeks, the next eleven books dealt with the universal history of the Trojan War up to the death of Alexander Magnus, the twenty-three other books narrate the events relating to the succession of Alexander and the sharing of Empire up to the Gallic War, taken by Julius Caesar (I Consulate). (Spoeri, 2001, 739) The last date mentioned by Diodorus refers to the colonization of Tauromenium, undertaken in the reign of Octavius (16, VII, 1), which can probably be dated around the years 36/21 before the Common Era. The correct year was probably 21 BC according to Albrecht 1979 but 36 BC to Meister (1997). Moreover, the issue of dating in the Historical Library is also the subject of controversy among scholars. Various dates mentioned by Diodorus are incorrect. A considerable part of the Historical Library (Howatson, 1993) has never come to us. There are, in their entirety, the books I to VI and XI to XX, but there are fragments of nearly all the other lost books, as evidenced by the English edition of the Loeb Classical. The fragments and excerpts (excerpts of Constantinople, Excerpta Hoescheliana forBooks from XXI to XXVI and Photius, from the volume XXXI) (Meister, 1997) and all the Diodorus's work is questionable for the establishment of the sources used by him.

Diodorus at this point, is not different from his predecessors: he appreciates and gives preference to the reports of battle, describing the behaviour of his characters; however, as our historian is a moralist who urges his readers to virtue, he gives preference in his narrative, to the role played by some figures in particular, who he clearly identifies with. ${ }^{11}$ These narratives happen quite often in the so-called historical books, that is, from the eleventh book (the books with historical narratives [after

10 The name given by Pliny the Elder, in a very playful way, in order to spoil the importance of Diodorus as a historian. A "bookstand of the history" Among the Greeks, Diodorus was the one who left the vagaries aside and headlined his history of library.

${ }^{11}$ From the perspective of his conceptions of history. 
the Trojan War] that remain integral up to the volume XX). Amazingly, the characters of Diodorus have in some way, "their biographies written," because the story is the court where everyone should be judged for their deeds, for the good or for the evil. Such biographies tend to show the judgments of values that Diodorus makes about the characters, and his "sympathy" and "antipathy" towards them is clear. The chosen passages are those that contain the term parádoxa with the sense of "unexpected" or "contrary to all expectations"; such passages also show the intervention of Fortune or Divine Providence, portraying that such individuals were worthy of some type of unexpected and sometimes supernatural intervention. In order to understand how Diodorus approaches these characters and the role they occupy in educational history, is necessary to examine some of these characters who played important roles in his narrative to such an extent that he set aside his concern about the "symmetry".

\section{Human models in the Historical Library: Epaminondas and the fate of Thebes}

The human models to which Diodorus dedicates to the Historical Library are, of course, warlords, generals who command armies and influence their subordinates, by the concrete example of their lives. The figure of the fearless warrior leader who fights alongside his men, urging them to fight, was central so that the war was successful, in addition to material rewards (which always existed), it was necessary a strong symbolic component, which made the soldier give his life to the leader, and he would do anything for him, even die for him. From the psychological point of view, the leadership needs to express certain values in order to emphasize certain virtues, which would be desirable that a leader possessed: body stiffness, courage, sense of somebody else's interests, pursue the good, ability to withstand adversity. The general or the strategist is one that should set an example, as he needs to discipline and take good care of his subordinates, to be able to link up with other leaders (heads of state and generals) and know how to break the set-ups of the opponent chiefs, or even attract the enemy to your side. ${ }^{12}$ It is on the battlefield that the qualities of the individual appear, since the conditions of existence and survival are stretched to the limit there. Men depend

12 I greatly appreciate the assistance provided by the Army Warrant Officer Antonio Fernando Lucas Camargo through conversations or recommendations of bibliographies. With a deep knowledge of military history he helps me to understand certain aspects of leadership and the military hierarchy and the psychological aspects implicit in the leadership of the generals on the soldiers. 
greatly on their partner and their behaviour during the battle. Thus, the relations and camaraderie that was created in the long years of serving together caught the attention of the Greek historians for the privileged narrative of the wars in their works. The examples abound in the HL in small "Biographies", but not in the conventional sense of the termconsidering that the only thing that matters to Diodorus are the qualities shown in the course of battle -- allow to understand how our author sees his behaviour in the most serious period of the existence, ie when it is being tested in all respects, when they could actually lose their lives and his soldiers. The way the troops see their general is extremely important, to his success as a leader manages the respect necessary for him to command. The recklessness and insolence of Perdiccas, for example, eventually made him lose his life through the hands of his own soldiers. His battle with Ptolemy, son of Lagos, was marked by moments of extreme tension, having the Nile as a scenery. Perdiccas intended to dominate Egypt that belonged to Ptolemy at all costs and did not hesitate to take reckless decisions, putting all his troops at risk. He set up his army as follows: on the left wing, he put the elephants and on the right wing, the horses, so that the heavy infantry could be collected and transported safely to the other side of the river. But an unexpected and unique phenomenon (parádoxon) happened, so they began crossing the river; if the first soldiers crossed without major problems, the following began to sink completely, causing general confusion. When crossing the ford of the river, with a huge amount of weight, the troops turned this stretch into a sort of quicksand, making the military uniform, with its extremely heavy armour, push them further into the bottom. There was a widespread panic, because many could not swim, the soldiers in a desperate attempt to get rid of the heavy military clothing, drowned themselves. At this moment, crocodiles appeared and attacked the soldiers, killing them mercilessly. About ten thousand soldiers perished, but no battle had been fought. ${ }^{13}$ Ptolemy and his troops, who watched everything on the other side of the river, rescued several soldiers, which put Perdiccas in a real awkward situation. Angry, some soldiers in the middle of the night, stormed the tent of Perdiccas and murdered him (HL, XVIII, XXXIV, XXXVI). The wisdom of Ptolemy made him realize that, besides fighting with the old Alexander's troops (and that therefore, knew well) would not be prudent, and crossing the Nile would be virtually impossible, due to its natural barriers (such as the strong stream of the Nile and the fearsome crocodiles). Perdiccas, on the other hand, was unable to think about the welfare of his soldiers, eager to defeat Ptolemy and therefore this blindness caused him to lose his most valuable asset as a general: the

${ }^{13}$ He brought fame to Diodorus, of philoanthopos. 
confidence of his men. His ambition for power and supreme command of the legacy of Alexander did not let him see that the signs and the apparent "calm" of Ptolemy were nothing more than prudence.

Such absurdities were not committed by the great Epaminondas, the Theban general responsible for two spectacular victories over the invincible Spartan army at Leuctra and Mantinea. His portrait wins memorable pages in the HL. Diodorus uses the devices of rhetoric and direct speech to highlight the best qualities of Epaminondas, who dedicated his life to Thebes. The city was frowned upon by the set of the Greek poleis, due to the fact that it remained during the Persian Wars, beside the enemy. But the famous strategist who had been educated in the Pythagorean philosophy, being responsible for the defeat of the Spartan army 14- unprecedented fact and that caused great shock and dismay throughout Greece -made even those who did not see Thebes under a positive bias, had over him, deep admiration. As the general Epaminondas was endowed with all the qualities of bravery and courage, he was also very cunning. An omen sent by the divinity warned the Lacedaemonians that they would lose their hegemony in Greece, which, according to Diodorus, had lasted five hundred years, and would also lose their empire. In fact, a comet was observed in the sky, which, for several nights, shone like a ball of fire, and shortly after, there was a battle that ended unexpectedly (paradóxos) to the Spartans, against all expectations (anelpístōs) (HL, XV, L, 1-2). Naturalist philosophers (phisikàs) looked for an explanation for this phenomenon, arguing that it was the result of natural causes, the Chaldeans of Babylon and other astrologers had predicted, successfully, such events because of the particular cycle that every star performed in its revolution, according to a determined course. So the wise men were not surprised (thaumázein) at this event (HL, $\mathrm{XV}, \mathrm{L}, 3) .{ }^{15}$ Diodorus stresses that this "torch of fire" in the sky was so

14 Diodorus says that the Lacedaemonians intended to enslave the Thebans, and at this moment, the Greeks were divided. Some thought it would be great if the Thebans did so, but others taken by compassion for them. The words of Diodorus are symptomatic: he anticipates the narrative by saying that many showed compassion for the miseries that awaited them " $(H L, X V, L I, 3)$ : the destruction of Thebes by Alexander the Great, described poignantly in the book XVII. I think that Diodorus strives to highlight in the $H L$ the importance of this moment for the Thebans in solidarity with them, because of the great suffering that they will be victims.

${ }^{15}$ A moment like this can be observed in XV, LXXX, 2-3, when Pelopidas (a Theban general) would march with his army, there was an eclipse of the sun. Many found this phenomenon very uneasy and stated that with the departure of the soldiers, it was the sun that covered the city that eclipsed: through these words, they predicted the death of Pelopidas, though he was not disturbed: it was his fate that should be met. In fact, Pelopidas died on the battlefield, but despite his death, he managed to achieve great glory (dóxes); besides he contributed greatly to the Theban rise. Diodorus adds: "We 
bright, that cast a shadow over the Earth only comparable to the moon. Epaminondas conducted several campaigns against the Peloponnese in order to isolate Sparta and resulted in the liberation of Messenia $(H L, X V$, LXVII, 1, "unexpectedly", paradóxous), causing the Lacedaemonians to lose a third of their territory. In the famous battle of Leuctra, the Thebans marched towards the enemy army, but they were daunted by the size of the Spartan army. The Beotarch held a meeting to discuss whether it would be really interesting to carry out a battle against an army far superior to theirs. The group of strategists divided, leaving the Epaminondas the "casting vote". As he did not want to decide alone something so important, Epaminondas used a ruse, since he knew the superstitious fear of omens that the soldiers believed. He chose the best men of Boeotia at the age to serve, counting the whole six thousand men; as they were leaving the city, he found a herald who pointed out that a blind slave had escaped. Epaminondas said, as it was customary, to look for the slave to return him to his owner. But the old soldiers saw the event as a fatal omen announcing the future, the young ones did not say anything for fear of appearing weak, but Epaminondas replied to all those who were considering the omen: "Defending the homeland is the only good omen "(Iliad, XII, 243, verse delivered by Hector). However the older soldiers, who had seen a lot happen, protested strongly, stating that the gods did not want the Theban army to keep on. After that statement, Epaminondas did not say anything else in full conviction that the consideration to the beautiful (kálon) and the care of the righteous person (dikaion) was the best omen (sèmeion). While many condemned the attitude of Epaminondas at the time, they were forced after the victory over the Lacedaemonians, to recognize his exceptional intelligence in the military art that had rendered to his country great service. In fact, for Diodorus, only the great men are able to go against the opinion of common sense and against all expectations (parádoxos), succeed magnificently. In their accounts of battle (in the 'historical' books), the role of the leader is always important to show the final result. After the battle of Leuctra, the Epaminondas forces massacred many fleers, and achieved a stunning victory: they had fought against the best in Greece and beat them, against all expectations (paradóxos), with only a handful of men and a much smaller troop than that of the Lacedaemonians, in the course of battle, they killed at least four thousand Spartan soldiers and fewer than three hundred Thebans were killed. The death of Epaminondas is told movingly: when he was about to die in the

give to Pelopidas, which deserved, because of his personal value, the consideration of all, the praise that history owes him" (HL, XV, LXXXI, 4). He always likes to say: "we never fail to tell good people, at his death [those who fell on battlefields], the praise due to him" (HL, XV, LXXXVIII, 1). 
battlefield (as every hero must die), he asked if they had saved his shield, someone said yes, the hero asks, still, who won the battle and the soldiers answered that were the Thebans - Epaminondas said it was "a good time to die." All around him wept and lamented the sad loss, mainly because Epaminondas died without having had the opportunity of having children. But the hero replied: "No, for Zeus, I leave two sons: the victory of Leuctra and of Mantinea"; as the spear that was in his chest was removed, he expired in peace (HL, XV, LXXXVII, 6). The oracles and their predictions were used to show the reader that the "great men" knew how to accept his fate with greatness of spirit and wisdom. Epaminondas died, but his name had the right to appear for the posterity, not failing to "inspire the good and provoke the bad, the fear of dishonour." The narrative follows, though, the Homeric line of reporting battles: the suspension of the time and events so that the hero has a "beautiful death" and an opportunity in his last moments, to give greater meaning to the deeds done in life.

The history of Thebes did not finish, however. Diodorus continues his account of the city taken by Alexander the Great (335-334), which he had already announced in the book XV. Firstly, his narrative inspired the author the most complete solidarity with the Thebans, despite his professed sympathy for the Conqueror. The divine signs are many in the narrative, revealing the Thebans all the doom ahead. Diodorus takes the reader into the deepest compassion for Thebes and its cruel fate.

As soon as Alexander took the throne of Macedonia, he acted with impetus to the Greek cities, which believed that his youth and limited experience in the military and political labours would incapacitate him to act with virtú before the unexpected Fortune. ${ }^{16}$ He quickly smothered with violence all the riots in the Greek póleis, alternating with moments of diplomacy. His biggest concern was the beginning of the conquest of Persia, a project cherished by his father, before the tragic outcome of his murder. Alexander sought the glory (dóxeis) and saw the riots of the infighting Greece and neighbours as nuisances to his best interests. When he thought that all problems were solved, new waves of uprisings exploded, especially at Thebes. The king, angered by this "annoyance", immediately sends there a Macedonian garrison, located in Cadmus, marching himself quickly with them, in order to harass Thebes. Meanwhile, the Thebans surrounded the area with fences and dispatched ambassadors all over Greece, with requests for help. They negotiated with the Argives, Eleusis and also with the Athens that in the figure of

16 But Alexander was not a neophyte: he had fought with his father Philip and temporarily taken his place. Diodorus narrates the life of Philip in the book XVI. 
the great orator Demosthenes, gave lots of weapons to the Theban resistance. The Lacedaemonians also sent troops to the Isthmus, in fact, such assistance was extremely misleading, given that the Athenians promised to give what they did not have and the peloponesians with Macedonian garrisons in Corinth and Sicyon, under the pressure of Antipater (Macedonian strategist and favourite of Alexander), could not do much. 17There was little time elapsed from the Treaty of Corinth, which provided in its terms an attempt to provide a "common peace". In any case, the possible "saviours" of Thebes decided to await the unfolding of the events, to know what position to take. Facing the fear (terror would be more appropriate) inspired by Alexander, nobody would dare to take the pro-Greece, without first making sure which way the wind was blowing. When the Thebans encountered the Macedonian troops, they were terrified, as they noted their obvious superiority. They quickly convened a council in order to discuss what actions to take: it was decided unanimously upon the war and fight to the end of their independence, the decision was approved by the people, passionately determined to fight. ${ }^{18}$ Alexander gave time for the Thebans to change their mind, which did not happen; he thought that nobody would have the audacity to face him, let alone a single city! They tried to negotiate, however, it was unsuccessful; the "opportunity" for the Thebans who wanted to defect and side with the Macedonians was given, which, however, also did not occur. Diodorus aims to show the reader that the honour of a city was at stake. If they were to die, they would die without the stain of desertion. The Theban Audacity seemed to have no limits. From the wall it was proclaimed: "Whoever desires, along with the Thebans and the Great King, free the Greeks and depose the tyrant of Greece, needed only to go to them" (HL, XVII, IX, 5). ${ }^{19}$ Alexander was extremely hurt and offended, taken by anger, he decided at that very moment, to destroy Thebes, but not before inflicting the greatest suffering and punishment on them. He prepared his war machines, for the siege.

\footnotetext{
17 With the departure of Alexander to Asia he was in charge of taking care of business in Europe as his strategist

18 Goukowsky points out that there was no unanimity in the decision of the "people", because the Theban constitution was an oligarchy. Nevertheless, Diodorus seeks to take advantage of his historical construction to show that in the calamity that struck Thebes, all were "united" in the misfortune. Book XVII, p. 18, n. 1.

19 The "medism" of the Thebans has always been emphasized by Greek authors, including Herodotus. It will have an important role in the outcome of the Theban tragedy. The Theban accounts of Diodorus do not use the indirect style common to all his narrative, but the events are so important, that reproduce the speech of the protagonists, which causes, undoubtedly, a strong dramatic effect. See HL, XI, XXVIII, 3, XI, XXIX, 1, XI, XXX, and XXXIII, on the "punishment" inflicted upon the Thebans by his "medism".
} 
Greece has trembled at the whole situation and everyone knew that they could do nothing, except watch the Theban annihilation. This attitude of the Thebans was extremely reckless for themselves, seeking their own disgrace and ruin. They seemed not to care or realize the dangers they ran and were preparing for the war, with a heart willing to fight. Then the gods began to send omens, warning them of what would actually happen.

A thin spider web was found in the sanctuary of Demeter: It had the size of a cloak and showed in their borders, a circle similar to one formed by the arc of the sky. The Delphic oracle gave the following answer: "This sign (sèmeîn), the gods reveal to all of you mortals, the Boeotian, above all, as well as their neighbours" (HL, XVII, X, 2). The Theban oracle gave them the following answer: "A web is woven to the happiness of one and the unhappiness of the other" (ibid.). This sign was received three months before the arrival of Alexander; when he approached the city, it was noticed that the statues of the public square were sweating and soon they would be covered with large drops. From the marshes of Onquestos, a sound like wailing was heard, in the Dirce River, a trickle of blood ran across the water, others also coming from Delphi, revealed that blood was seen on the roof of the temple built by the Thebans with remains of the Phocidians. Experts in the interpretation of the signs said that the spider web announced the departure of the gods of the city, the colour of the rainbow from the sky, a storm of various disasters and the sweat of the statues, an unusual event, and finally, the blood that appeared in several different places announced that a great slaughter would occur in the city. As the gods were clearly warning about the woes ${ }^{20}$ that the city would be victim, it was advised not to risk a battle to be decided through a war. The best would be to send ambassadors to try to resolve the situation in a more secure way (HL, XVII, X, 4-5), that is, by diplomatic channels. But the Thebans remained unconvinced: They recalled the glorious days of the battle of Leuctra that, although that was very difficult, they had achieved victory in an unexpected manner (anelpistōs) and miraculous (thaumastôs), thanks solely to their courage. In their

\footnotetext{
${ }^{20}$ In the siege of Tyrus, similar events also occurred: the people had a vision that Apollo was abandoning the city. Extraordinary occurrences (parádoxon) and other wonders caused widespread panic in the crowd. The citizens made gold chains to tie to the feet of the God in order for him not to leave the city. On the side of the Macedonians it was not different: preparing for the siege, they saw sea monsters of incredible dimensions, however, it did not cause them any harm. Those who have seen a similar extraordinary spectacle (parádoxon) were greatly impressed: each side saw the apparition as a manifestation of Poseidon in their favour (HL, XVII, XLI, 5-6)
} 
patriotic exaltation, they had completely lost prudence at the expense of courage.

The preparations for the siege, organized by Alexander lasted about three days. ${ }^{21}$ The Conqueror divided his army into three bodies: the first had the order to attack the fortifications established before the city, the second to do battle directly with the Thebans, the third would act as reserve soldiers to the ones who were to miss. For his part, the Thebans put their riders inside the built fort and opposing them, the foreigners and the banned on the walls. Women and children ran to the shrines in order to plead with God to save the city from all dangers. The trumpets sounded the signal to start the fight, both sides heard cries of war and a battle was fought hand-to-hand, starting a massive slaughter. It was almost impossible to resist the Macedonian pressure, because of the number and weight of the phalanx. The Thebans resisted because of their courage and the regular physical exercise, but the number of injured and their cries of pain reverberated throughout the field. Macedonian cries exhorted "not to stain their reputation and their past bravery shamefully" and the Thebans "not to let their children and relatives at risk of being reduced to slavery, nor their country crumble under the blows of the furious Macedonian! They should, instead, remember the battles of Leuctra and Mantinea [...]" (HL, XVII, XI, 5). The value of the Thebans left them in doubt for a while, the course of the battle. Alexander, who watched everything, seeing the enthusiasm with which the Thebans defended their freedom and the laxity that took control of the Macedonians, commanded the reserves to go to the battlefield, as his army suffered heavy losses. The Thebans were increasingly convinced that they could win the Macedonian army and disregarded any imminent danger, saying that "the Macedonians recognized that they were inferior to the Thebans". Observing that, amid the general confusion, during the hand-to-hand, the door leading into the city was undefended, Alexander sent Perdiccas, one of his best generals, and a sufficient number of soldiers, to get into the city by surprise. Just when the Thebans destroyed the first Macedonian phalanx and resisted vigorously the second with great hope of victory, they were surprised at the city being taken by the garrison of Perdiccas. The cavalry made rapid movement back to the city in order to defend it, which, amid the general confusion caused great mortality among their own countrymen, skinning them under the hooves of the horses. When

\footnotetext{
${ }^{21}$ Goukowsky states that the narrative of Diodorus causes skepticism because of the speed of the preparations. The editor of the book XVII states that the narrative of Diodorus has a character clearly rhetorical. That is why it interests me. The narrative is entirely coherent with the concept of history so well explained in his preface in the Book I, to incite men to a 'moral arete'. Book XVII, p. 172, n. XI, 1.
} 
leaving the citadel, the Macedonian soldiers massacred the Thebans who were returning.

The account of Diodorus is full of humanity and compassion: the Macedonian made a proclamation that aimed to treat the Thebans in a more cruel way than that the worst enemies are treated. Far from showing themselves cowards, the Thebans did not kneel before the Macedonian troops, nor sought clemency. On the contrary, they offered themselves to receive the blows, in fact, they had in the soul the spirit of freedom and were far from kneeling before the Macedonian arrogance (HL, XVII, XIII, 1-2). Women and children were massacred, without pity and, therefore, relied on the help of the Greeks themselves "regardless of their relationship to race." Many cities that had hatred of Thebes seized the moment to take revenge, as the Thespians, the Plateus, those of Orchomenus and many others. 22 Diodorus is keen to point out, expressions of personal hatred, at a time that should inspire compassion: "the Greeks were ruthlessly put to death, and regardless of their relationship to race, were massacred by their neighbours, without which the community of the language made the latter experiment any shame at all "(HL, XVII, XIII, 6). Over six thousand Thebans were killed and over thirty thousand were made prisoners: an incredible amount of precious objects was plundered. The king met with the board to deliberate (still!) The outcome that should be given to Thebes. The general opinion was that Thebes should suffer an inexorable punishment, showing that, prior to serving the interests of the Greeks, they served the interests of the barbarians (the Persians): "At the time of Xerxes, they did not fight alongside the Persians and campaigned against Greece? Were not they, only them among all Greeks, who were honoured as benefactors in the Persian court, where, before the Great King, had seats for the Theban ambassadors? "(HL, XVII, XIV, 1-2). Many others recalled episodes in which the Thebans remained against Greece inciting the council (synédrion) to hatred against them. It was resolved "that the city would be completely destroyed, selling the prisoners, that in all Greece the Thebans in exile would possibly be extraditable, that no Greek could give asylum to a Theban" (HL, XVII, XIV, 3). The city was destroyed, so that it would

\footnotetext{
22 In 373, the Thebans destroyed Plataea and looted the thespian. In 364 they destroyed Orchomenus, massacring the men and selling women and children. Both cities were restored by Philip, father of Alexander. Such acts performed by Thebes led to a general disapproval in Greece, which explains in part the attitude towards the Thebans at the moment. However, what Diodorus wants to emphasize in this passage is that, faced with such hardship, good men should show their magnanimous pity on the fate of the victims, which really is for very few. See Book XVII, n. XIII, 5, p. 174. The commentary of Goukowsky cites Xenophon (Hellenics, 6, 3, 1) and refers to Diodorus himself in XV, XLVI, 5-6.
} 
also serve as an example, so that no longer any Greek would dare to revolt against anything. The prisoners were sold and a considerable sum of four hundred and forty talents was raised. A delegation went to Athens, in order to claim the extradition of ten speakers who carried out hostile policies to the Macedonians, including Demosthenes and Lycurgus. The city was taken by a great embarrassment and deep anxiety: on the one hand they tried to safeguard the prestige of the city, but on the other hand, the ruin of Thebes provoked feelings of fear: did these misfortunes really happen? It was amazing that such horror and misfortune had happened to their neighbours. Numerous speeches were delivered in the convened assembly, and Photius, considered "a good man" who led a policy opposed to that of Demosthenes, claimed that the Thebans should imitate the behaviour of Leos of Zakythos, who voluntarily sought death for his country. Those who did not wish to die for it were cowards and lacked virility. As soon as he said these words, he was expelled by the people of the assembly, with tempestuous manifestations that totally disapproved of him. Demosthenes spoke, and with a speech carefully prepared, he convinced the people, urging them to take pity, clearly showing that such men should be saved. Demarade proposed to save those who were in danger and skillfully drafted a document in favour of the speakers, promising to punish, according to the laws, those who deserved punishment. The people approved the drafted document and ratified it: together with others, he sent the decree to Alexander, asking also about the Theban exiles, if the Athenians had the right to collect the fleers. His oratory skill obtained complete success and convinced Alexander to agree with the propositions. According to Goukowsky, (DIODORE DE SICILE: 1976, 27) things did not happen as easily as Diodorus narrates. It took at least two successive embassies, the first of which was poorly received. I think that Diodorus prefers to adopt the narrative that "things were easier, in part to" save "the image of Alexander, who was carried away by anger and was not quite what one might call " Greek "despite his fine Hellenic education. It is clear in the diodorian narrative that Alexander, despite his declared filohelenism, was interested even in his personal projects and used the Greeks to achieve them. In that sense, analyze him from the Machiavellian perspective, that evil should be applied at once and very slowly, expresses the personality of the Conqueror. Writing as early as Roman times, Diodorus shows in his universal history the important role played by the Greeks, especially as a moral power of exempla. He tells the woes of Greece, terrifying moments in which "Greeks killed Greeks", or the hateful tyranny of the Thirty in Athens (Book XIV), when the Lacedaemonians acted abominably. Going through the Historical Library, we see the profound admiration that the Greek history inspired him, and 
much of his work is devoted to Greece, to its great men and its great deeds. Could Greece be a model for the oikouménē? I think the answer is positive and the miraculous omens and events that permeate his "Greek" narrative play an important role in the internal organization of his history project so well explained in the preface. "It is thanks to the history [and to eloquence] that the Greeks were much better than the barbarians, those cultivated people over the ignorant beings. It is also thanks to it that one man can dominate a crowd "(HL, I, II, 6). Nothing better than narrate the history (especially Greek) to encourage men (Greek and Hellenistic populations and Romans in particular) to a practical ethics: it is a unique opportunity to see the great men act in life's difficulties and facing unexpected situations that the Fortune, capricious, places on the routes to be followed by them. "Chance" contributes so that Diodorus can better explain the history of Epaminondas and insert it into his project of history: those who act well in adverse situations are blessed by "chance". The happiness to be able to die at the highest glories that a "beautiful death" provides, leaving behind the achievement of Mantinea and Leuctra, makes Epaminondas an undisputed hero of the Historical Library.

\section{Ancient Sources}

DIODORE DE SICILE. Bibliothèque Historique. Paris Les Belles Lettres, Livro XVII,1976

HERÓDOTO: Histórias. Lisboa: Edições 70, 1994. Tradução de Maria de Fátima Silva e José Ribeiro Ferreira.

HESÍODO. A teogonia em português. HESÍODO; Teogonia. São Paulo: Iluminuras, 1991. Tradução de Jaa Torrano.

\section{Bibliographic References}

ALBRECHT em Der kleine Pauly. Muechen. Deutscher. Taschenbuch Verlag, 1979.

CANFORA. A biblioteca desaparecida. Histórias da Biblioteca de Alexandria: São Paulo: Cia das Letras, 2001.

CLAUSEWITZ. Da Guerra: São Paulo: Martins Fontes, 2003.

FARRINGTON. Diodorus Siculus. Universal Historian. Swansea, 1937, p. 5 apud LENS-TUERO. Sobre la naturaleza histórica de la Biblioteca Histórica de Diodoro de Sicília. Granada: Universidad de Granada,1994. 
GOUKOWISKY,PAUL. Notice. In: Bibliothèque Historique. Livre XVII. Paris: Les Belles Lettres, 1976.

Introduction. In: Bibliothèque Historique. Livre XVII. Paris: Les Belles Lettres, 1976.

HOWATSON (Dir.). Dizionario delle letterature classiche. Torino: Giulio Einaudi, 1993.

LEGRAND, Ph.-E. In: HÉRODOTE. Histoires. Paris: Les Belles Lettres, 1967, v. III.

MEISTER, Klaus. Diodorus Siculus. Der Neue Pauly. Enzyklopädie der Antike. Editado por von Hubert Cancyk und Helmuth Schneider. Altertum V. III. Stuttgart \& Weimar: J. B. Metzler, 1997. p. 592-594.

PÖTSCHER. Tychē. In: Der kleine Pauly. Muechen. Deutscher. Taschenbuch Verlag, 1979. V. 5. Schaf-Zythos, pp. 1016-1017.

ROMILLY. História e razão em Tucídides: Brasília: UnB, 1998.

SCHWARTZ. Griechische Geschichtsschreiber. Diodoros von Agyrion. In: Real-Enciclopädie der Classischen Altertum Swissenschaft. Stuttgart: J. B. Metzer Verlag, 1903. v. 9.

SPOERRI, Walter. Diodorus Siculus von Agyrion (Sizilien). In: Lexikon der Alten Welt. Duesseldorf: Albatroz/Patmos Verlag, 2001. 